\title{
Assessment of cyanide content in cassava (Manihot Esculenta Crantz) varieties and derived products from Senegal
}

\author{
Séri Serge Guédé, Souleymane Traoré, Kouakou Brou \\ Department of Food Sciences and Technology, Laboratory of Nutrition and Food Safety, Nangui Abrogoua University, 02 BP 801 \\ Abidjan 02, Ivory Coast
}

\section{Email address:}

trasouley@yahoo.fr (S. Traoré)

\section{To cite this article:}

Séri Serge Guédé, Souleymane Traoré, Kouakou Brou. Assessment of Cyanide Content in Cassava (Manihot esculenta Crantz) Varieties and Derived Products from Senegal. International Journal of Nutrition and Food Sciences. Vol. 2, No. 5, 2013, pp. $225-231$.

doi: $10.11648 /$ j.ijnfs.20130205.12

\begin{abstract}
We investigated cyanide levels in four cassava varieties and some derived products from Senegal. The study was conducted on fresh tubers by sampling in three longitudinal positions $(1 / 4 ; 1 / 2 ; 3 / 4)$ and four radials $(A, B, C$ and $D)$. In addition, the sampling of derived products was carried out by product types (chip dried, graded, unpressed and pressed attieke, gari and flour). Cyanide contents were determined using differential pulse polarography. Results showed that whatever the variety considered, there was no significant difference between the total HCN content in cassava slices (1/4; $1 / 2 ; 3 / 4)$. Similarly, results from different layers (A, B, C and D) did not highlight the radial variability of the total HCN content. We showed a variable cyanide content $(\mathrm{mg} \mathrm{HCN} / \mathrm{kg}$ fresh material) in cassava varieties: 104.3 $\pm 3.9 ; 171.6 \pm 5.4$; $231.2 \pm 10.2 ; 270.8 \pm 12.0$ for Kombo, Nigeria, Soya and Gniargui respectively. The detoxification processes (attieke, gari and flour) indicated a reduction rate in excess of $80 \%$ and may be effective to reduce the cyanide content in cassava root down to a tolerable level $(<50 \mathrm{mg} / \mathrm{kg})$.
\end{abstract}

Keywords: Cassava Root, Varieties, Cyanide, Derived Products, Detoxification

\section{Introduction}

Cassava (Manihot esculenta Crantz) is an extensively cultivated tuber crop and a staple food for millions of people in the tropical regions of Africa, Latin America and Asia. Globally, in terms of annual production, it is the fifth most important food crop after maize, rice, wheat and potato [19]. While starchy tuberous roots are the main food source, the young leaves, which are high in protein, are also consumed, particularly in Africa [1,30,32]. Despite all the usefulness of cassava, its use as a food source is limited by its perishability, its low protein content and its potential toxicity [37, 39]. Cassava contains two cyanogenic glucosides, linamarin and a small amount of lotaustralin, which are catalytically hydrolyzed to release toxic hydrogen cyanide ( $\mathrm{HCN})$ when the plant tissue is crushed $[5,31]$. Several varieties of cassava have been identified and grouped into bitter and sweet depending on the quantity of linamarin in the tuber. The consumption of cassava and its derived products which contain large amounts of $\mathrm{HCN}$ may be responsible for such visible manifestations as goiter and cretinism [10, 3, 16], tropical ataxic neuropathy [34] and Konzo [26].

In some countries such as Côte d'Ivoire, Benin and Nigeria, people have quickly recognized the need to transform cassava into derived products (Cossettes, Chikwangue, Fufu, Gari, Attieke, Tapioca [8, 2] whose gain is usually higher than the fresh roots. The processing methods used traditionally are sun drying, soaking and fermentation followed by cooking. These processing methods could lead to reduce the cyanide content in cassava products $[7,13,35,36]$ to improve its palatability and convert it into a storable form.

It is worth indicating that, in Senegal, the level of cassava consumption is very low. In this country, it is generally consumed as vegetable in the daily meals of households [17]. In addition, a virtual lack of processing units and inadequacy of cassava processing equipment are noted [24]. With its potential for processing, cassava could be an alternative to imported food in order to diversify food and ensure food safety [21] in Senegal. 
The aim of this study was to estimate the rate of cyanide in four cassava varieties from Senegal and assess some cassava detoxification processes.

\section{Materials and Methods}

\subsection{Experimental Design}

This study was conducted on 4 cassava varieties from Senegal: Soya, kombo, Gniargui and TMS 30572 (origin from Nigerian). We established two batches. Each batch contained three tubers per variety from the department of Tivaouane, one of the three departments of Thies regions along the western part of Senegal.

Fresh cassava from the first batch were planted in July 2009, harvested 20 months following planting and immediately sent to Belgium within 48 hours by DHL for analysis.

The Soya cassava varieties from the second batch were planted in July 2010, harvested 9 months after planting, packed in plastic bags, stored at $-60^{\circ} \mathrm{C}$ until July 2011 and sent to Belgium by ITA employees for analysis.

Cassava-derived products such as grated, pressed and unpressed cassava, chips, attieke, gari and flour were also used.

\subsection{Preparation of Derived Products}

The preparation of derived products was performed at the Institute of Food Technology (ITA) in Senegal. The different products are:

Cassava chips:

Fresh cassava was peeled manually with kitchen knife, washed, cut into small pieces and dried.

Cassava flour:

For cassava flour, the tubers were peeled, washed, grated and pressed to extract the remaining juice. After pressing, the cassava compact blocks were grinded and sieved into flour to remove any waste, then they were sun-dried to reach a moisture content of 12 percent.

Gari:

Fresh cassava was peeled, washed, grated into small pieces and fermented for two days. The product obtained was then pressed. The pulp was grinded, sieved and roasted with a gari roasting pan up to reach a moisture content of 10.5 percent.

Attieke:

The fresh cassava roots were peeled, washed, cut into pieces and milled. The paste obtained was fermented, normally for approximately $12 \mathrm{hrs}$, by mixing with a traditionally prepared inoculum, comprising cooked cassava that was anaerobically fermented for $36 \mathrm{hrs}$ at ambient temperature. The paste thus formed was pressed to remove the juice. The mashed cake was then crumbled, sieved and processed into semolina that was partially sundried, cleaned and finally steam-cooked into attiekesemolina.

\subsection{Samples Preparation and Cyanide Measurements}

Samples preparation and cyanide measurements were performed at the laboratory of analytical chemistry at Gembloux Agro-Bio Tech, University of Liege, in Belgium.

\subsubsection{Samples Preparation}

\section{Sampling of Cassava Tubers}

Upon receipt, fresh cassava tubers were immediately stored at $-20^{\circ} \mathrm{C}$ to avoid enzymatic hydrolysis of cyanogenic glycosides. After 24 hours of storage, they were sampled.

Slices $(1 / 4,1 / 2,3 / 4)$ of Samples for Each Variety

The desired position $(1 / 4,1 / 2,3 / 4)$ was observed on varieties of tubers (Fig. 1). Using a sharp knife, $1 \mathrm{~cm}$-thick slices were taken at this position and then cut into small pieces. These pieces were immediately immersed into polypropylene bags containing liquid nitrogen for about 1 minute and then grinded with a small grinder (IKA). The powder obtained was put in small bottles that were labeled, sealed and stored at $-20^{\circ} \mathrm{C}$. We proceeded in the same way for all varieties.

Layers (A, B, C and D) of Samples for Each Variety

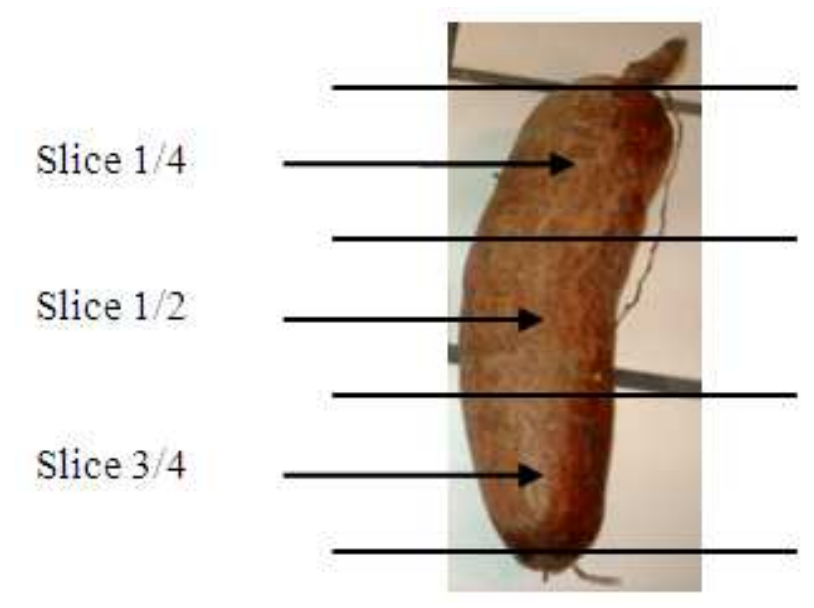

Figure 1: Positions of different slices on cassava root. Slice 1/4 (Head); Slice 1/2 (Middle) and Slice 3/4 (Tail).

Cassava is composed of several layers. The tissues in the layers were separated into four parts (Fig. 2): the cortex (part A) and B-C- and D-part tissues. The cortex could easily be removed from parenchymal tissue by hand. The periderm on the cordex was discarded. B- part tissue was a white parenchymal tissue which was 2 to $3 \mathrm{~mm}$ thick next to the cortex. C- part tissue was a yellow parenchymal tissue, 7 to $8 \mathrm{~mm}$ thick, next to B-part tissue. D- part tissue, 16 to $18 \mathrm{~mm}$ thick, was the remaining core tissue. Each separated tissue fraction was weighed. The entire fraction was used for analysis. While the various layers were formed as above one by one, for the samples from the first batch, they were simultaneously formed for those from the second batch. 


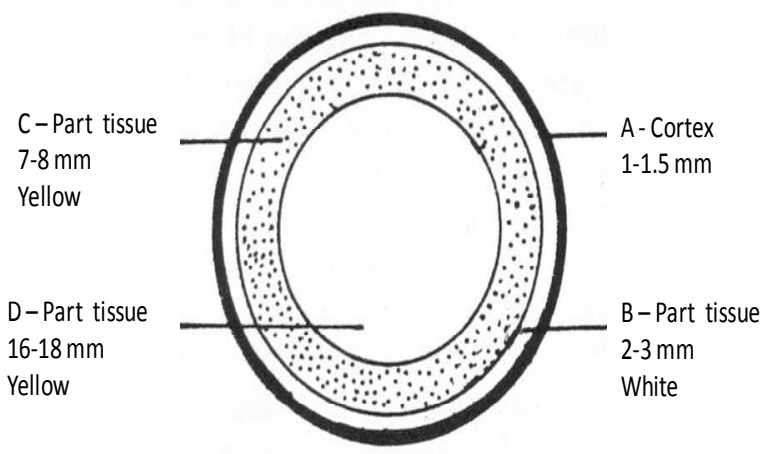

Figure 2: Scheme of the various tissues in cassava root: $A$ - Cortex; $B$ Part tissue (White); $C$ and D-Part tissue (Yellow)

Sampling of Derived Products

Such wet derived products as attieke grated, pressed and unpressed were immediately stored at $-20^{\circ} \mathrm{C}$, whereas others adequately dry derived products were kept in the dark.

\subsubsection{Cyanide Measurements}

Total Cyanide Contents in Cassava Roots

The measurements of total cyanide contents in cassava roots were performed according to the auto-enzymatic method [6].

The sample $(1 \mathrm{~g})$ of finely ground cassava was incubated in $20 \mathrm{ml}$ acetate buffer $\left(\mathrm{pH} \mathrm{5.5)}\right.$ at $37^{\circ} \mathrm{C}$ for 18 hours. After incubation, the samples were cooled at room temperature $\left(20^{\circ} \mathrm{C}\right)$ and then, $4 \mathrm{ml}$ of $\mathrm{NaOH}$ were added. The cassava samples were placed into a distillation flask round bottom containing distilled water. The flask was heated at $100^{\circ} \mathrm{C}$ in a digital temperature-controlled dry bath and its central neck was connected to the condenser glass directly attached to two bubbler in series containing each $10 \mathrm{ml}$ of $0.1 \mathrm{M}$ $\mathrm{K}_{2} \mathrm{CO}_{3}$. After, $10 \mathrm{ml}$ of $\mathrm{H}_{2} \mathrm{SO}_{4}$ were added to the flask by one of the two side necks to facilitate evaporation of HCN in sample. In the second lateral neck, a very thin tube was inserted, directly immersed into the solution and allowing the entry of air.

The air flow was controlled by vacuum pump placed after the second bubbler. During distillation, the HCN released was constantly carried through the glass condenser and trapped in the first bubbler. The second is considered as a control measure. After 15 minutes, the solution of the first bubbler was collected in a flask $(50 \mathrm{ml})$ and made to volume with $0.1 \mathrm{M} \mathrm{K}_{2} \mathrm{CO}_{3}$. The anion $\mathrm{CN}$ - was measured using a polarograph (Metrohm E 506 with Stand Polarecord 663 VA Stand) in differential pulse mode. Oxygen dissolved in the solution was removed by bubbling nitrogen (inert gas) for 5 minutes. Finally, the registration of the polarogram was done in an unstirred solution.

Residual Cyanide Contents in Cassava-Derived Products The residual cyanide contents in cassava-derived products measurements were performed according to the method described above with slight modification by adding the commercial linamarase.

Cyanide Content calculation

The polarogram height peaks measurements were expressed as $\mu \mathrm{A}$. Ion $\mathrm{CN}$ - concentration (C) was calculated relative to the reference solution.

Cyanide content (T) (mg HCN/kg matter).

$$
\mathrm{T}=\frac{\mathrm{C}^{*} 50}{\text { Control sample }}
$$

\subsection{Statistical Analysis}

All values are reported as means \pm SEM. Analysis of variance (ANOVA) with two classification criteria, combined model mixt and fisher test for $\alpha=0.01$ [14] were used to express the variation of cyanide contents in cassava. Statistical calculations were performed (on the entire data set) using MINITAB. Where a significant effect was detected, a paired Student's t-test was used to determine levels of statistical significance between groups.

\section{Results and Discussion}

\subsection{Total Cyanide Contents in Cassava Slices $(1 / 4,1 / 2$, 3/4) and Varieties}

Statistical analysis showed that:

-For fixed principal factor (slice type), Fisher calculated (Fcal) < Fisher read (Fre), we accept $\mathrm{H}_{0}$. Total cyanide contents in cassava slices showed no significant difference;

-For the random accessory factor (variety type), Fcal > Fre, we reject $\mathrm{H}_{0}$. Total cyanide contents in cassava varieties were significantly different.

The total cyanide contents in different slices and cassava varieties from the first batch are presented in table 1. Result showed the significant difference between cassava varieties $(p<0.05)$. Total cyanide contents did not differ in each slice. Kombo variety presented the lowest total cyanide content in each slice. The significant difference between total cyanide contents in cassava varieties obtained in this study is consistent with the patterns reported by [15], [21] and [4] who found a significant difference between $\mathrm{HCN}$ concentrations in cassava varieties. Based on total cyanide contents, cassava can be classified into three groups as follows: sweet varieties $(<50 \mathrm{mg} / \mathrm{kg})$, intermediate varieties $(50-100 \mathrm{mg} / \mathrm{kg})$ and bitter varieties $(>100 \mathrm{mg} / \mathrm{kg})[9,38$, $39,33]$. In view of our results, we could say that the cassava varieties studied would be bitter, due to their high level of cyanide contents. The reduction of cyanide content would be important to make these products agreeable for consumption. 
Table 1: Total cyanide contents in slices and cassava root $\left(1^{\text {rst }}\right.$ batch) by variety

\begin{tabular}{|c|c|c|c|c|c|}
\hline Type of sample & Kombo & Nigeria & Soya & Gniargui & $\begin{array}{l}\text { Significance } \\
p\end{array}$ \\
\hline Slice $1 / 4$ & $93.5 \pm 3.7^{\mathrm{d}}$ & $182.9 \pm 8.4^{\mathrm{c}}$ & $210.1 \pm 6.9^{b}$ & $228.7 \pm 2.4^{\mathrm{a}}$ & $* *$ \\
\hline Slice $1 / 2$ & $105.1 \pm 3.2^{\mathrm{d}}$ & $156.7 \pm 1.7^{\mathrm{c}}$ & $218.4 \pm 6.3^{b}$ & $291.1 \pm 3.5^{\mathrm{a}}$ & $*$ \\
\hline Slice $3 / 4$ & $114.1 \pm 0.6^{\mathrm{d}}$ & $175.0 \pm 4.1^{\mathrm{c}}$ & $264.9 \pm 3.1^{\mathrm{b}}$ & $292.5 \pm 5.5^{\mathrm{a}}$ & $* *$ \\
\hline Cassava root & $104.2 \pm 3.9^{d}$ & $171.6 \pm 5.4^{\mathrm{c}}$ & $231.2 \pm 10.2^{b}$ & $270.8 \pm 12.0^{\mathrm{a}}$ & $* *$ \\
\hline
\end{tabular}

Total cyanide content is expressed in $\mathrm{mg} \mathrm{HCN} / \mathrm{kg}$ of fresh matter

a,b,c,d Means in the same a row with different superscript letters are significantly different $(\mathrm{P}<0.05)$

$* * \mathrm{p}<0.01 ; * \mathrm{p}<0.05$

\subsection{Total Cyanide Contents in Layers $(A, B, C, D)$ of Cassava Roots}

Table 2 presents total cyanide contents in the cortex, B, $\mathrm{C}$ and $\mathrm{D}$ part tissue in the first batch of cassava roots. We identified a significant difference between the layers $(p<0.05)$. The total cyanide contents found in the different layers (A-B-C-D) were lower than those in slice $(1 / 4 ; 1 / 2$; $3 / 4)$. This difference could be explained in terms of the difference in cutting method to obtain layers and slices for sampling. We established that the total cyanide content was high in the cortex and decreased sharply towards the center of the root in each variety. These results are complied with those achieved by [29, 25] who showed that along the proximal to the distal end, the cyanide content decreases sharply. Our results suggest that it is safe to remove or exclude the cortex portion before eating the root.

Table 2: Total cyanide contents in different layers of cassava root $\left(1^{\text {rst }}\right.$ batch) by variety.

\begin{tabular}{lllll}
\hline $\begin{array}{l}\text { Type of } \\
\text { sample }\end{array}$ & Kombo & Nigeria & Soya & Gniargui \\
\hline $\begin{array}{l}\text { A- Cortex } \\
\text { B- Part }\end{array}$ & $24.0 \pm 3.7^{\mathrm{a}}$ & $40.8 \pm 5.1^{\mathrm{a}}$ & $52.9 \pm 3.4^{\mathrm{a}}$ & $105.6 \pm 6.7^{\mathrm{a}}$ \\
tissue & $7.9 \pm 0.5^{\mathrm{b}}$ & $11.1 \pm 2.8^{\mathrm{b}}$ & $9.5 \pm 0.6^{\mathrm{b}}$ & $23.3 \pm 1.2^{\mathrm{b}}$ \\
$\begin{array}{l}\text { C- Part } \\
\text { tissue }\end{array}$ & $4.3 \pm 1.1^{\mathrm{c}}$ & $8.9 \pm 1.3^{\mathrm{b}}$ & $9.4 \pm 3.3^{\mathrm{b}}$ & $9.7 \pm 1.3^{\mathrm{c}}$ \\
$\begin{array}{l}\text { D- Part } \\
\text { tissue }\end{array}$ & $1.2 \pm 0.1^{\mathrm{d}}$ & $5.3 \pm 1.8^{\mathrm{c}}$ & $3.9 \pm 1.1^{\mathrm{c}}$ & $8.3 \pm 0.3^{\mathrm{c}}$ \\
\hline
\end{tabular}

Total cyanide content is expressed in $\mathrm{mg} \mathrm{HCN} / \mathrm{kg}$ of fresh matter: ACortex; B- Part tissue (White). C and D- Part tissue (Yellow). a,b,c Means with different superscripts in the same column are significantly different $(\mathrm{P}<0.05)$

\subsection{Comparison of Total Cyanide Contents in Layers of Cassava Root of Soya Varieties}

Total cyanide contents in layers of cassava roots of Soya varieties from the first and second batch are showed in Table 3.
Table 3: Comparison of total cyanide contents in layers of cassava root of Soya varieties

\begin{tabular}{llll}
\hline Type of sample & Soya $\mathbf{1}^{\text {rst }}$ batch & $\begin{array}{l}\text { Soya } 2^{\text {nd }} \\
\text { batch }\end{array}$ & $\begin{array}{l}\text { Significance } \\
\boldsymbol{p}\end{array}$ \\
\hline A- Cortex & $52.9 \pm 3.4$ & $446.9 \pm 22.7$ & $* *$ \\
B- Part tissue & $9.5 \pm 0.6$ & $361.8 \pm 6.1$ & $* *$ \\
C- Part tissue & $9.4 \pm 3.3$ & $348.2 \pm 12.4$ & $* *$ \\
D- Part tissue & $3.9 \pm 1.1$ & $405.4 \pm 4.6$ & $* *$ \\
\hline
\end{tabular}

Total cyanide content is expressed in $\mathrm{mg} \mathrm{HCN} / \mathrm{kg}$ of fresh matter: ACortex; B- Part tissue (White); C and D- Part tissue (Yellow) $* * \mathrm{p}<0.01$ : significant

Results showed that the total cyanide contents for the second batch were higher than those attained with the first batch, whatever the layers considered $(p<0.01)$. This difference could firstly be explained by the sampling method and secondly by the harvest period and the age of the tubers. For Soya of second batch, the sampling method adopted leads to greatly reduced exposure time for the layers, which would limit the hydrolysis of cyanogenic compounds. As for cassava age, results attained in this study were similar to those reached by $[22,21]$ in other varieties. These authors showed that cyanide contents in cassava root decreases with age. Furthermore, in Thies region, June to October corresponds to high rainfall and November to May corresponds to low rainfall. Harvesting second batch samples in June 2011 (the relatively dry period recorded just before harvesting) could explain the high cyanide contents. Our results are in agreement with those of $[12,13,18]$ who showed the high cyanide contents when rainfall is low and low cyanide contents when rainfall is high.

\subsection{Cyanide Contents in Cassava Roots and some Derived Products}

Total and residual cyanide contents in four cassava varieties and some derived products were presented in Figures 1, 2, 3 and 4 for Kombo, Nigeria, Soya and Gniargui respectively. Our results showed that cyanide concentration decreases in cassava products compared to cassava fresh roots, whatever the varieties considered. We 
established a reduction rate of $\mathrm{HCN}$ approximately at $15 \%$, $70 \%$ and $80 \%$ in cassava chips grated, unpressed and pressed respectively (Fig 1, Fig 2, Fig 3 and Fig 4). For the finished derived products, results revealed a reduction rate about $85 \%$ for attieke and above $95 \%$ in dehydrated products (gari, flour). Residual cyanide contents in cassava chips obtained in this study were similar to those of [11]. By contrast, our results were higher than those achieved by [27] which vary between 1 and $10 \mathrm{mg} / \mathrm{kg}$. This difference could be explained by the use of sweet varieties by these authors and the improved processing methods to produce cassava chips. The low residual cyanide found in attieke, gari and flour could be explained by the degradation of cyanogenic compounds through unit operations such as grating, fermentation, pressing, drying and cooking [7, 13, 28, 35, 36, 33]. Moreover, the lower HCN contents found in gari than in attieke could be explained by the fact that gari was obtained through dry cooking while attieke was obtained by steam cooking. Further studies could be conducted to confirm these hypotheses. Residual cyanide contents in the cassava-derived products studied were lower than $50 \mathrm{mg} / \mathrm{kg}$. As the lethal dose for humans is 50 $\mathrm{mg} / \mathrm{kg}$, we might think that the processing methods of attieke, gari and flour could be effective to reduce the amount of HCN down to tolerable levels.

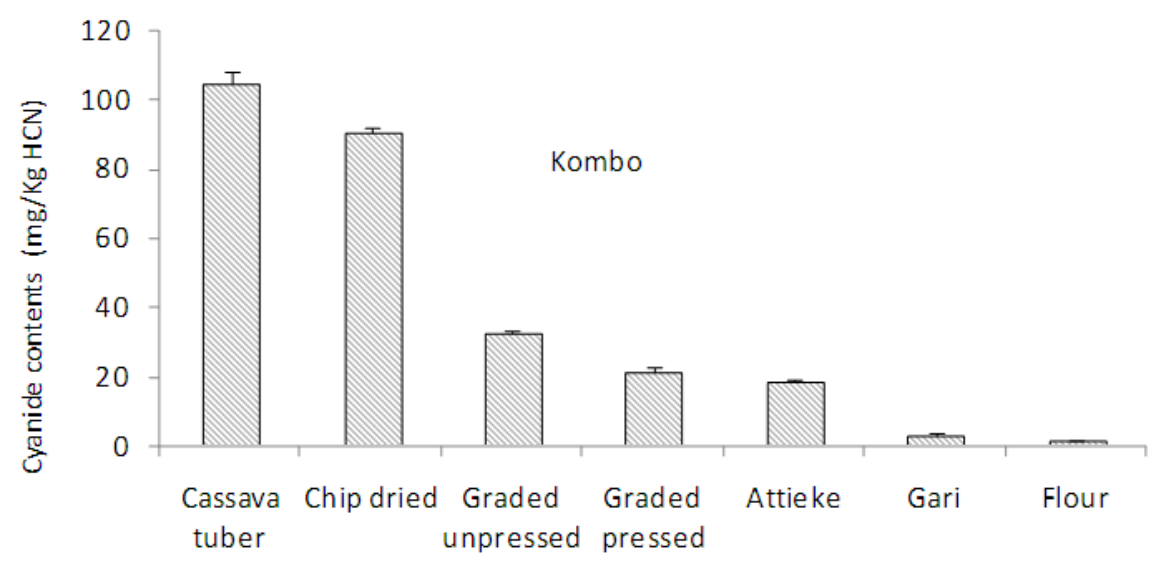

Figure 3: Cyanide contents in cassava root of Kombo variety and some derived products

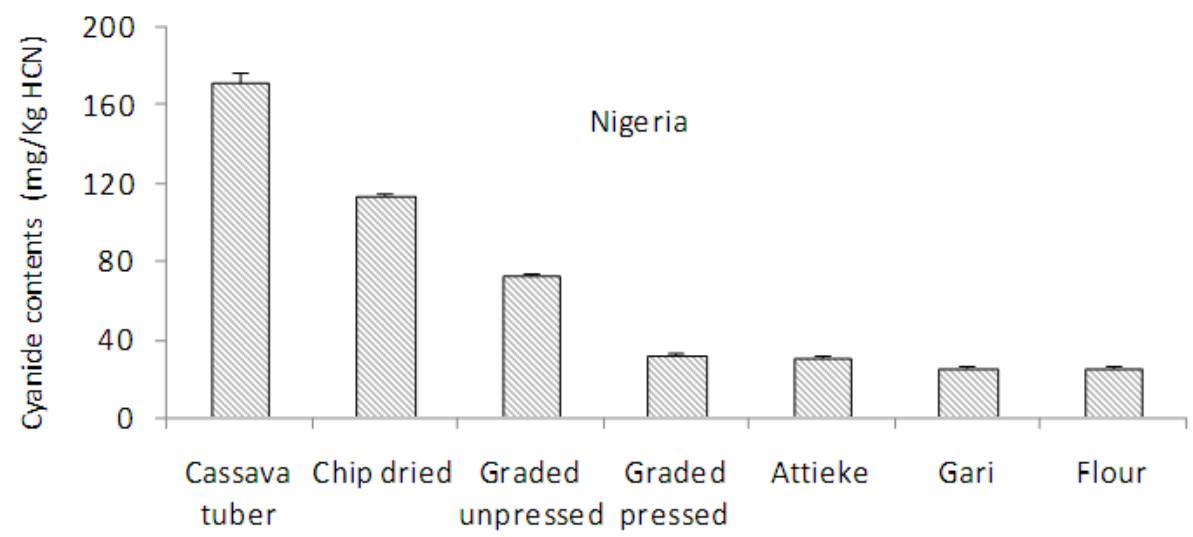

Figure 4: Cyanide contents in cassava root of Nigeria variety and some derived products

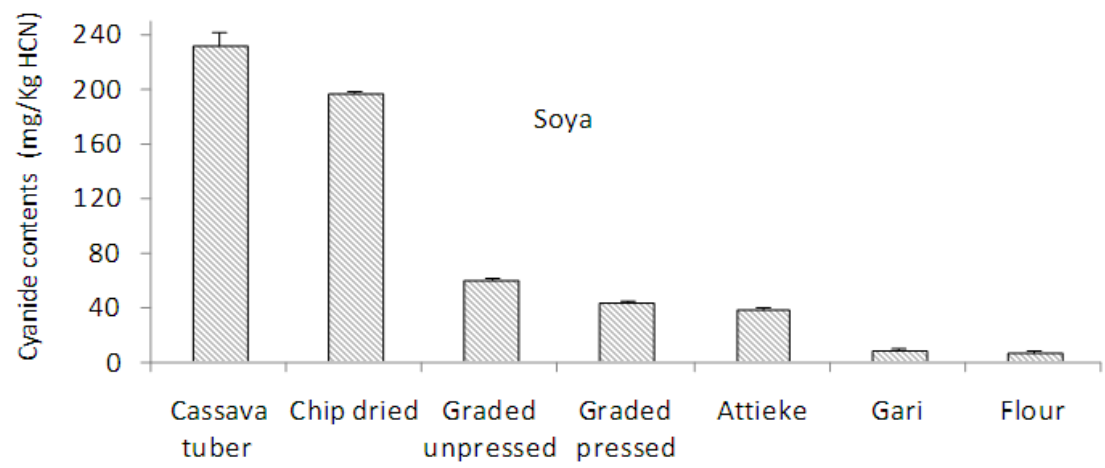

Figure 5: Cyanide contents in cassava root of Soya variety and some derived products 


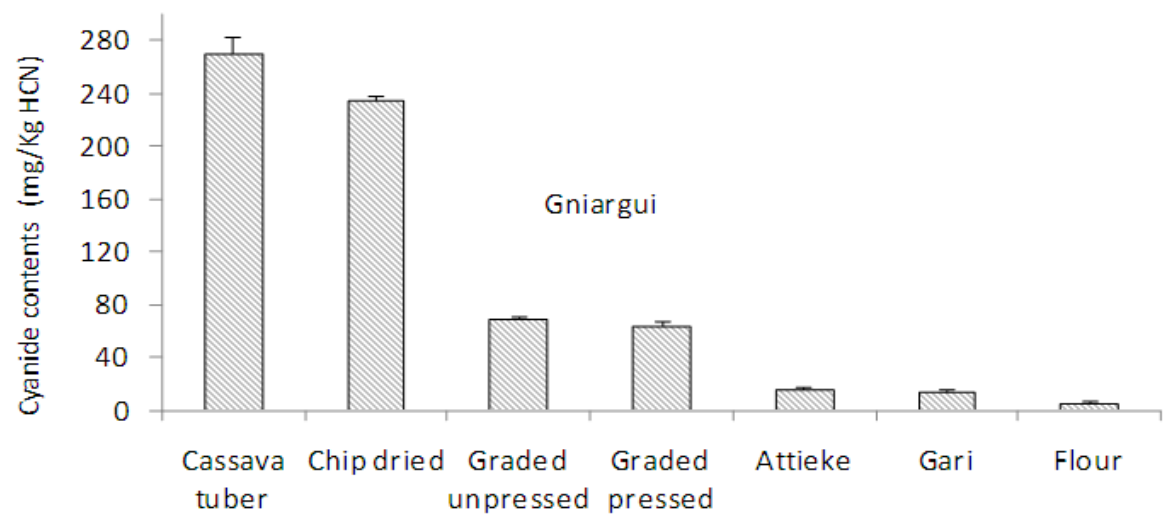

Figure 6: Cyanide contents in cassava root of Gniargui variety and some derived products

\section{Conclusion}

This study revealed that the total cyanide contents in cassava roots were higher than $100 \mathrm{mg} \mathrm{HCN} / \mathrm{kg}$ and these cyanide contents varied in cassava varieties from Senegal. We established that the methods of cassava processing were able to reduce total cyanide contents in cassava roots. Moreover, gari and cassava flour prepared from Kombo and Soya varieties showed the residual cyanide content below the level of $10 \mathrm{mg} \mathrm{HCN} / \mathrm{kg}$ that is considered safe [20]. These results may be used on a household and cottage-industry to ensure food safety.

\section{Acknowledgements}

The authors gratefully acknowledge FNRAA cassava (National Fund for Agricultural Research and Food Processing) for their financial support. We are grateful to Dr. Momar Talla Gueye, ITA researcher; project coordinator who freely accepted to participate in this study.

\section{References}

[1] A.U. Achidi, O.A. Ajayi, M. Bokanga and B. Maziya-Dixon, "The use of cassava leaves as food in Africa". Ecology of Food and Nutrition, 44: 423-435, 2005

[2] G. Amani, C. Nindjin, B. N'zue, Tschannen A and D. Aka,"Potentialités de la transformation du manioc (Manihot Esculenta Crantz) en Afrique de l'Ouest". Actes du $1^{\text {er }}$ Atelier International, Abidjan, 4-7 juin, 48-79, 2007

[3] A. Akintonwa, O. Tunwashe and A. Onifade, "Fatal and non-fatal acute poisoning attributed to cassava-based meal". Acta Horticulturae, 375: 285-288, 1994

[4] F.N.A. Aryee, I. Oduro, W.O. Ellis and J.J. Afuakwa, “The physicochemical properties of four samples from the roots of 31 varieties of cassava". Food Control, 17: 916-922, 2006.

[5] C. Balagopalan, G. Padmaja, S.K. Nanda and S.N. Moorthy, "Cassava nutrition and toxicity. In: Balagopalan, C. (Ed.). Cassava in Food, Feed and Industry". CRC Press, Florida, USA, pp. 13-36, 1988
[6] J.P. Baudoin, J.P. Barthélemy and V. Ndungo, "Cyanide production of the lima bean, Phaseolus lunatus L. Genetic variability in the primary and secondary gene pools and in some intraspecific hybrid, in Bulletin de Recherche Agronomique de Gembloux", XXVI, n 3, pp. 367-388, 1991

[7] J.H. Bradbury, "Processing of cassava to reduce cyanide content". Cassava Cyanide Disease Network News (CCDN), 3: 3-4, 2004

[8] M. Bokanga, "CASSAVA: Post-harvest Operations, éd. International Institute of Tropical Agriculture (IITA)", Ibadan, Nigeria, 220 p, 2001

[9] G.G. Bolhuis, "The toxicity of cassava roots". Journal of Agriculture and Science, 2:176-185, 1954

[10] P. Bourdoux, P. Seghers and M. Mafuta, "Cassava Products: HCN content and detoxcification processes, In Delange F., Iteke F., Ermans A., ed. Nutritional factors involved in the goitrogenic action of Cassava", Ottawa, Int. Development Research Center, pp. 234-246, 1982

[11] E.A. Burns, H.J. Bradbury, R.T. Cavagnora and M.R. Gleadow. "Total cyanide Content of cassava food product in Australia". Journal of food composition and analysis, 25: 79-82, 2012

[12] A.P. Cardoso, M. Ernesto, J. Cliff, S.V. Egan and J.H. Bradbury, "Cyanogenic potential of cassava flour: field trial in Mozambique of a simple kit". International Journal of Food Sciences and Nutrition, 49: 93-99, 1998

[13] A.P. Cardoso, E. Mirone, M. Ernesto, F. Massaza, J. Cliff, R.M. Haque and H.J Bradbury, "Processing of cassava roots to remove cyanogens". Journal of food composition and Analysis, 18: 451-460, 2005

[14] J.J. Claustriaux and R. Palm, "« Chapitre 7 : Analyse de la variance », cours de maitrise statistique des procédés", ULg - Gx ABT - SIMA, pp 142 - 163, 2011

[15] R.D. Cooke, "An enzymatic assay for the total cyanide content of cassava (Manihot Esculenta Crantz)". Journal of the Science of Food and Agriculture, 29: 345-352. 1978

[16] F. Delange, L.O. Ekpechi and H. Rosling, "Cassava cyanogenesis and iodine deficiency disorders". Acta Horticulturae, 375: 289-293, 1994

[17] A. Diouf, "Rapport final du projet d'appui au programme spécial de la relance de la filière manioc au Sénégal”, pp 5- 


\section{6,2006}

[18] M. Ernesto, A.P. Cardoso, D. Nicala, E. Mirione, F. Massaza, J. Cliff, M.R. Haque and J.H. Bradbury, "Persistent konzo and cyanide toxicity from cassava in Northern Mozambique”. Acta Tropica, 82: 357-362, 2002

[19] FAOSTAT. 2011. Food and Agriculture Organization of the United Nations statistics database retrieved 2 February, 2013 from: www.faostat.fao.org.

[20] FAO/WHO. "Joint FAO/WHO food standards programme, Codex Alimentarious Commission, XII Supplement 4 FAO”. Rome, pp: 12-45. 1999

[21] G. Gomez, M. Valdivieso, D. De La Cuesta and S.T. Salcedo, "Effect of variety and plant age on the cyanide content of whole-root cassava chips and its reduction by sun- drying". Animal Feed Science and Technology, 11: 57-65, 1984

[22] G. Gourez, 1982. Le manioc, le cyanure et la nutrition animale. La toxicité du manioc et la thyroïde : Compte rendu d'un colloque tenu à Ottawa, Canada, du 31 mai au 2 juin 1982

[23] T.M. Gueye, "Rapport: Le manioc, la meilleure alternative au riz pour les populations sénégalaises", Walfadjri, Contributions, 2008

[24] T.M. Gueye, "Rapport: Journée portes ouvertes sur la transformation du manioc, Ministère des Mines, de l'Industrie et des PME de la République du Sénégal", Institut de Technologie Alimentaire, 2009.

[25] A. Hidayat, N. Zuraida, and I. Hanarida, "The cyanogenic potential of roots and leaves of ninety nine cassava cultivars". Indonesian journal of Agricultural Science, 3: 2532,2002

[26] W.P. Howlett, "Konzo: a new human disease entity". Acta Horticulturae, 375: 323-329, 1994

[27] J.Y. Jamin, B.L Seiny and C. Floret, 2003. Savanes africaines : des espaces en mutation, des acteurs face à de nouveaux défis, Actes du colloque, mai 2002, Garoua, Cameroun, Prasac, N'Djamena, Tchad - Cirad, Montpellier, France.

[28] B.L. Koffi, E.C. Djedji and A. Kamenan, "Dégradation de la teneur en acide cyanhydrique au cours de la transformation du manioc et qualité microbiologique de l'attiéké", Actes de l'Atelier "Potentialités à la transformation du manioc en Afrique de l'Ouest" - Abidjan, 4-7 Juin, 262 - 265, 2007

[29] M. Kojima, N. Iwatsuki, E.S. Data, C.D.V. Villegas and I. Uritani, "Changes in cyanide content and linamarase activity in wounded cassava roots". Plant Physiol, 72: 186-189, 1983

[30] V. Lebot, "Tropical root and tuber crops: cassava, sweet potato, yams and aroids". CABI, Wallingford, UK, 2009.

[31] J.M. McMahon, W.L.B. White and R.T. Sayre. "Cyanogenesis in cassava (Manihot esculenta Crantz)". Journal of Experimental Botany, 46: 731-741, 1995

[32] J.A. Montagnac, C.R. Davis and S.A. Tanumihardjo, "Nutritional value of cassava for use as a staple food and recent advances for improvement". Comprehensive Reviews in Food Science and Food Safety, 8: 181-194, 2009

[33] B. Nambisan, "Strategies for elimination of cyanogens from cassava for reducing toxicity and improving food safety", Food and Chemical Toxicology, 49: 690-693, 2011

[34] B.O. Osuntokun, "Chronic cyanide intoxication of dietary origin and a degenerative neuropathy in Nigerians". Acta Horticulturae, 375: 311-321, 1994

[35] C.I. Owuamanam, J.O. Iwouno, N.C. Ihediohanma and L.I. Barber, "Cyanide reduction, functional and sensory quality of gari as affected by $\mathrm{pH}$, temperature and fermentation time Pakistan”. Journal of nutrition, 9: 980-986, 2010

[36] C.I. Owuamanam, C.C. Ogueke, S.C. Achinewhu and I.S. Barimalaa, "Quality characteristics of gari as affected by preferment liquor, temperature and duration of fermentation". American Journal of Food Technology, 6: 374-384, 2011

[37] J.E. Richard, "Tannins levels in cassava, a comparison of methods of analysis". J. Sci. Food. Agric, 37: 37-42, 1985

[38] H. Rosling, "Cassava toxicity and food security". Uppsala, Sweden, Tryclc Kontakt, 40 p. 1987

[39] R. Rukiya, "Détermination quantitative du cyanure dans le manioc (variétés F100, 02864, 30085/28, 30344/6 Mpelolongi) ". Inédit. Mémoire. Faculté des sciences, Université de Kinshasa. 1988 